\section{E-LETTER RESPONSE TO}

\section{doi 10.1308/003588407X209464}

I Taylor. Editorial Comment: MRSA - a major surgical problem. Ann $R$ Coll Surg Engl 2007; 89: 655

doi 10.1308/003588408X242376

\section{All encompassing approach}

\section{BENJAMIN DEAN}

Nuffield orthopaedic Centre, Oxford,Oxon UK

\section{CORRESPONDENCE TO}

Benjamin Dean, SHO in Surgery, Nuffield orthopaedic Centre, Oxford,Oxon UK. E: bendean@doctors.net.uk

There were some very interesting pieces of research in the October edition of the Annals of The Royal College of Surgeons of England. Whilst the editor mentions several useful measures in combating MRSA infection including hand washing, careful prescribing and eliminating sources of cross infection, I feel that several more important measures were not mentioned.

Lord Darzi's interim report outlined some additional ways in which our approach could be improved; ${ }^{1}$ these included guidelines on the isolation of patients, more screening of elective admissions and some ideas with a slightly dubious evidence base such as the 'bare below the elbows' strategy and a 'deep clean'.
Some countries (such as The Netherlands) have been far more successful than the UK at controlling MRSA with a policy that includes isolating and screening high-risk patient groups, the screening of low-risk groups, and the strict isolation of carriers and the treatment of people carrying MRSA. ${ }^{2}$ There is a growing body of opinion that our approach may not be quite as comprehensive as it should be. ${ }^{3}$

I just wonder if the strict isolation of patients is possible when we have a growing pressure on acute beds, with total acute bed numbers actually falling and bed occupancy rates at an all time high. ${ }^{4}$ There are also other significant factors that are not being addressed which include the immense pressure on trusts to meet Government targets, which then result in patients being moved far too frequently and often without infection control being respected. I think a holistic approach is needed and this will not happen until the NHS is run with far less political meddling.

\section{References}

1. NHS. Our NHS Our future: NHS next stage review - interim report. $<$ http://www.dh.gov.uk/en/Publicationsandstatistics/Publications/ PublicationsPolicyAndGuidance/DH_079077>.

2. Daha T, Bilkert M. MRSA: the Dutch approach. Am J Infect Control 2004; 32: e89.

3. Editorial. MRSA: how politicians are missing the point. Lancet 2005; 365: 1203.

4. Wanless D, Applebuy J, Harrison A, Patel D. Our Future Health Secured? A review of NHS funding and performance. <http://www.kingsfund.org.uk/ publications/kings_fund_publications/our_future.html>. 